\title{
Hemşirelik Bölümü Kişilerarası İlişkiler ve Terapötik İletişim Dersi Öğretim Programının Değerlendirilmesi
}

\author{
Derya KAVGAOĞLU*, Nurten ELKINN**
}

\section{Öz}

Amaç: Araştırmayla İstanbul Gelişim Üniversitesi Hemşirelik Bölümü 2017-2018 Bahar dönemi "Kişilerarası İlişkiler ve Terapötik İletişim” lisans dersinde uygulanan öğrenen merkezli öğretim programı tasarımının öğrenci görüşlerine göre değerlendirilmesi amaçlanmaktadır.

Yöntem: Araştırma, betimsel araştırma kapsamındaki genel tarama modeliyle gerçekleştirilmiştir. Araştırmanın veri toplama aracı, Kavgaoğlu ve Alcı tarafından geliştirilen “CIPP Program Değerlendirme Ölçeğı”dir. Araştırmanın çalışma grubunu, 2017-2018 Bahar döneminde İstanbul Gelişim Üniversitesi Sağlık Yüksekokulu Hemşirelik lisans programında Kişilerarası İlişkiler ve Terapötik İletişim dersine devam eden 52 öğrenci oluşturmaktadır. Araştırmanın veri analizi SPSS v25.o programıyla gerçekleştirilmiştir. Araştırmanın istatistiksel çözümlemeleri betimsel analiz, güvenilirlik, farklılık ve korelasyon analizleri ile yapılmıştır. Çözümlemelerde non-parametrik teknikler olan "Mann Whitney U Testi”, "Kruskal Wallis Analizi”, "Spearman's Rho Testi” kullanılmıştır. Modelin ara değişkenlerinin aracılık etkisini belirleyebilmek için "Hiyerarşik Regresyon Analizi” yapılmıştır.

Bulgular: Araştırmanın süreç ve çıktı değişkenleri arasında istatistiki olarak anlamlı bir ilişki bulunmuştur ( $\mathrm{p}<0.05)$. Bağlam bağımsız değişkeninin, süreç ara değişkeni olarak çıtıyı istatistiki yönden etkilediği ve kısmi ara değişken etkisinin bulunduğu tespit edilmiştir ( $\beta=0.667$ $\mathrm{p}=0.000<0.05)$. Bağlam-1 ve girdi düzeyleri ile cinsiyet arasında erkek öğrenciler lehine; Bağlam-1 düzeyi ile duygusal yardım beceri düzeyleri arasında duygusal yardım becerisinin orta düzey olduğunu ifade eden öğrenciler lehine anlamlı farklılıklar bulunmuştur $(\mathrm{p}<0.05)$.

\footnotetext{
Özgün Araştırma Makalesi (Original Research Article)

Gelis / Received: 28.09.2018 \& Kabul / Accepted: 16.01.2019

${ }^{*}$ Dr. Öğr. Üyesi, İstanbul Gelişim Üniversitesi, Sağlık Bilimleri Yüksekokulu, Sosyal Hizmet Bölümü, İstanbul, Türkiye, E-posta: dkavgaoglu@gelisim.edu.tr ORCID ID https://orcid.org/o0oo-0001-5926-3081 ** Dr. Öğr. Üyesi, İstanbul Gelişim Üniversitesi, Sağlık Bilimleri Yüksekokulu, Çocuk Gelişimi Bölümü, İstanbul, Türkiye, E-posta: nelkin@gelisim.edu.tr ORCID ID https://orcid.org/oooo0002-9470-2702
} 
Öğrencilerin CIPP boyutlarındaki düzeyleri ile alandaki eğitimleri, akademik başarı öz değerlendirme düzeyleri ve sosyal ilişki öz değerlendirme düzeyleri arasında istatistiki olarak anlamlı bir farklılık saptanmamıştır ( $\mathrm{p}>0.05)$.

Sonuç: Araştırma sonucunda öğrenen merkezli öğretimin, programın kişisel, sosyal ve iş sonuçlarına dönük çlktıları üzerinde etkili olduğu belirlenmiştir. Süreçte uygulanan öğrenen merkezli öğretime ilişkin öğrenci görüşlerinin alandaki eğitim geçmişi, algılanan akademik ve sosyal yeterlilik değişkenlerine göre farklılaşmadan tüm boyutlarda yüksek olduğu, bununla birlikte cinsiyet ve duygusal yardım becerisine yönelik algı gibi bireysel farklılıkların öğrenme ortamının farklı yorumlanmasında etkili olduğu görülmüştür. Yüksekokul genelinde akademik başarı ve öğrenci memnuniyetinin artırılması için derslerin yetişkin öğrenme prensiplerini ve bireysel farklılıkları da dikkate alan öğrenen merkezli öğretim tasarımlarıyla planlanmasının ve terapötik iletişim derslerinin hemşirelik müfredatı içinde farklı öğretim kademelerinde genişleyerek tekrar eden spiral bir tasarımla verilmesinin faydalı olacağı düşünülmektedir.

Anahtar Sözcükler: Müfredat, öğretim modelleri, eğitsel teknikler, eğitsel değerlendirme, hemşirelik eğitimi araştırması, iletişim programları.

\title{
Evaluation of Interpersonal Relationships and Therapeutic Communication Lesson Curriculum
}

\begin{abstract}
Aim: The purpose of this study is to evaluate the learner-centered curriculum design applied in the Istanbul Gelisim University Nursing Department, in 2017-2018 spring semester "Interpersonal Relationships and Therapeutic Communication" undergraduate course, according to students' opinions.
\end{abstract}

Method: The research was carried out through a survey model within descriptive research. Research data collection tool is "CIPP Program Rating Scale" that was developed by Kavgaoğlu and Alc1. The study group of the research consists of 52 students who attend the Istanbul Gelisim University School of Health Nursing undergraduate program in "Interpersonal Relationships and Therapeutic Communication" course in 2017-2018 spring semester. The survey data analysis was carried out with SPSS v25.o program. Statistical analysis of the study was done by descriptive analysis, reliability, difference and correlation analysis. Non-parametric techniques, such as "Mann Whitney U Test", "Kruskal Wallis Analysis" and "Spearman's Rho Test" were used in the analyzes. "Hierarchical Regression Analysis" was performed to determine the mediating effect of the model's intermediate variables.

Findings: There was a statistically significant relationship between the process variable and the output of the study ( $<<0.05)$. It was found that the context independent variable influenced 
the output of the process as an intermediate variable and had a partial intermediate variable effect $(\beta=0.667 \mathrm{p}=0.000<0.05)$. Findings with Context-1 between input levels and gender was in favor of male students; Significant differences were found in favor of students who stated that the level of emotional help was moderate between Context-1 and emotional support skill levels $(\mathrm{p}<0.05)$. There was no statistically significant difference between the levels of the students in the CIPP dimensions and the training in the field, academic achievement selfevaluation levels and social relationship self-evaluation levels ( $\mathrm{p}>0.05)$.

Conclusion: As a result of the research, it has been determined that learner-centered teaching has an impact on the output of the program towards personal, social and business results. It has been found that the student's perceptions of the learner-centered teaching applied in the process are high in all dimensions without being differentiated according to the perceived academic and social competence variables and that individual differences such as perception of gender and emotional support skill are effective in a different interpretation of the learning environment. In order to increase academic achievement and student satisfaction across the vocational school, it is thought that it is useful to plan the courses with learner-centered instructional designs that take consideration into adult learning principles and individual differences, and to provide therapeutic communication courses in a nursing curriculum with repeated spiral design by expanding in different instructional levels.

Keywords: Curriculum, instructional models, educational technics, educational assessment, nursing education research, communication programs.

\section{Giriş}

Sağlıkta iletişim olgusu, dijitalleşen dünyada profesyonel sağlık pratiklerinin insanla insani bir şekilde nasıl buluşturulacağı sorusuna verilecek cevabın çerçevesini çizmektedir. İletişim, sağlık profesyonelleri tarafından çoğu zaman ihmal edilerek tıbbın kör noktasını oluşturabilmektedir. Sağlık eğitim programlarına doğru öğretim tasarımlarıyla eklenecek iletişim dersleri bu konuda henüz problem oluşmadan alınabilecek en değerli önlem ve yapılacak en doğru yatırım olabilir.

Sağlık Bakanlığı'nın sağlık eğitimi ve sağlık insangücü durum raporuna göre Türkiye’de aktif çalışan sağlık personeli sayısı 514.955 olup bunun 149.012'sini hemşireler oluşturmaktadır. Hemşireler sağlık çalışanları içinde yaklaşık \%29’luk bir dilimi temsil etmektedirler ${ }^{1}$. Türkiye İstatistik Kurumu'nun, sağlı personeli başına düşen kişi sayısı raporuna göre ise 2016'da hemşire başına düşen hasta sayısı 522'dir. Aynı raporla 
sunulan bir diğer istatistik ise 2016 yılında 150.00o hastanın sağlık turizmi, 252.640 hastanın ise turistin sağlığ kapsamında ülkemize gelmiş olduğudur² ${ }^{2}$ Bu durumda hemşireler sağlık çalışanları içinde önemli bir çoğunluğu temsil ediyor olsalar bile doğrudan iletişim kurmakla yükümlü oldukları hasta sayısının çokluğu, onların hasta merkezli hemşirelik yapma motivasyonunu önemli ölçüde olumsuz etkileyebilmektedir.

Kayıt altına alınarak istatistiklere yansıyan hasta şikâyetleri ve sağlık personeline yönelik olarak artan şiddet haberleri sağlık hizmetlerinin müdahale edilerek iyileştirilmesi gereken problem alanlarını gösteren somut verilerdir. Sağlık Bakanlığı'nın sağlık çalışanlarına yönelik şiddetin önüne geçmek üzere 2012 yılında başlayan beyaz kod uygulamasına son beş yılda yaklaşık 67.00o sağlık çalışanı şiddet başvurusunda bulunmuştur3. Sağlık çalışanlarına yönelik şiddet olaylarını araştırıp alınması gereken önlemleri belirlemek amacıyla kurulan meclis araştırması komisyonu görüşme tutanaklarında, iletişim olgusu, son dönemlerde sayısı giderek artan sağlıkta şiddet vakalarının en önemli nedenlerinden biri olarak ele alınmış, hekimlerin ve sağlık çalışanlarının çoğu zaman hastaların anlayacağı dilden konuşamadıklarının, bunun farkında olmadıklarının, bu durumun da şiddet olaylarına zemin hazırlayabildiğinin altı çizilmiştir4,5. Literatürde ülkemizdeki hastaların hemşirelik hizmetlerine yönelik memnuniyeti üzerine yapılmış az sayıda çalışma olduğu görülse de iletişimin hasta memnuniyetsizliği içindeki payını vurgulayan istatistik ve araştırmalar bulunmaktadır610. Bununla birlikte hemşirenin olumlu tutum ve davranışlarının hasta üzerindeki olumlu etkilerini destekler nitelikte araştırmalar da mevcuttur ${ }^{11-16}$. Özkan'ın ${ }^{8}$ da ifade ettiği gibi tıbbi vizyonun hasta duygularının etkilerinden faydalanmayı öğrenerek ilerlemesi önemlidir. Nitekim hastalar hastalıklarıyla baş başa kaldıklarında kin, öfke, kaygı, depresyon, kötümserlik ve yalnızlık gibi duygular yaşayabilirler. Her bir düşünce, duygu ve inanç insan vücudunda nörokimyasal bir işlem için zemin hazırlar ${ }^{17}$. Yani zihin yapılarımız, duygu, düşünce ve inançlarımız sağlığımız üzerinde doğrudan etkilidir. Bir sağlık profesyonelinin, hastalığı iyileştirmek kadar doğru iletişimle hastanın bu duygusuyla başa çıkmasına yardımcı olabilmenin de önemli bir tıbbi değer taşıdığını bilmesi çok değerlidir ${ }^{8}$ Avrupa Birliği Kriterleri doğrultusunda ve ulusal çerçevede hemşirelik eğitiminin minimum standartlarını belirleyerek standardizasyonu sağlamayı hedefleyen Hemşirelik Ulusal Çekirdek Eğitim Programında da bu doğrultuda, etkili iletişim becerilerini kullanabilme, mesleki etik ve değerlere uygun davranabilme, yaşam boyu öğrenme, sorun çözme, eleştirel düşünme, sağllk personeli 
ve diğer disiplinlerle işbirliği, meslektaşlarına ve topluma model olma, değer ve sosyal hakların evrenselliğini gözetme gibi ulusal yeterliliklerin altı çizilmektedir ${ }^{18}$. Program bu temalar çerçevesinde öğrenmelerin gerçekleştirilebilmesine imkân tanıyan iletişim ve kişilerarası ilişkiler dersine de açıkça yer vermektedir. İletişimde temel kavramlar, insanın davranış özellikleri, iletişim teknikleri, özel durumlarda iletişim, ekip içi iletişim, hasta yakınlarıyla iletişim ve çatışma yönetimi gibi teorik kapsamı referans alarak uygulamaya doğrudan yansıması beklenen şu davranışları da açıkça vurgulamaktadır; insanın davranış özelliklerini değerlendirebilme ve buna uygun yaklaşımı sergileyebilme, etkili iletişim tekniklerini kullanabilme, özel durumları uygun iletişim teknikleriyle yönetebilme ${ }^{18}$. 01 Nisan 2013 tarihi itibarıyla Hemşirelik Ulusal Çekirdek Eğitim Programı (HUÇEP) Çalışma Grubu tarafından hazırlanan programın ülke genelinde tüm hemşirelik lisans eğitimi programlarının en az \%6o'ını oluşturması hedeflenmiştir ${ }^{18}$. Bununla beraber, iletişim ve kişilerarası ilişkiler dersinin müfredatta yer alması yeterli değildir. Kazanımlara ulaşmada belirleyici olan, dersin nasıl bir öğretim tasarımıyla verileceğidir. Nitekim en fazla kavrama düzeyinde ve sıklıkla bilişsel kazanımlarla sınırlı, teorik ve didaktik işleyiş yerini öğrenen merkezli uygulamalara bırakmadığı takdirde profesyonel bir sağlık iletişiminin duyuşsal kazanımlarının hayata geçirilmesi de mümkün olamayacaktır.

Öğrenen merkezliliğe doğru kurumsal değişim yeni bir tasarı değildir. 20. Yüzyl başlarında eğitimde salt konu alanına değer veren eğitim planlamacılarına karşı tepki olarak ilerlemecilik hareketiyle gündeme gelmiştir ${ }^{19-21}$. Geleneksel müfredat tasarımının dayandığı öğretimsel paradigmada bilgiye akademik disiplin kurallarına göre sahip olunabilir; bilginin alıcısı olan bütün bireyler aynı yolla öğrenir; öğrenme için harcanan zaman önemlidir; yapılan hata negatif anlam taşır ve kişinin yetersizliğini ifade eder ${ }^{22}$. Öğrenen merkezli müfredat ise öğrencileri karmaşık ve biraz da zorlayıcı öğrenme işinin içine çekmek, öğrenme süreçleri üzerinde onlara bir miktar kontrol yetkisi vererek motivasyon ve güç sağlamak, neyi nasıl öğrendiklerine ilişkin düşündürmek, sınıfı herkesin öğrenme gündemini paylaştığı bir topluluk olarak kabul ederek işbirliğini teşvik etmek temel kabulleri üzerinde şekillenir ${ }^{23}$. Öğrenen merkezli eğitime geçiş değişen topluma hızlıca adapte olabilen otonom ve yaratıcı bireyler yetiştirme arayışı içinde önemli bir adımı temsil eder. Öğrenme merkezli teknikler, günümüz işgücünün kesinlikle temel kabiliyetleri olarak düşünülen inovatif düşünmeyi ve yaratıcılığı besler ${ }^{22}$. Bu araştırmada öğrenen merkezli öğretim tasarımı ders bazında 
uygulanmıştır; bununla birlikte, klasik düzende ard arda sıralanmış masaların olduğu sınıflarda dekorasyonu modernize edip işbirlikli sınıf kültürünün oluşmasını beklemek gibi sadece bireyselleştirilmiş sınıflar oluşturup öğrenen merkezli eğitimin kurum genelinde uygulandığını düşünmek de yanlış olacaktır. Nitekim lise sonrası eğitim kurumlarında akademik yatırımların kalbine öğrenmeyi yerleştirmek, kavramları, prosedürü, müfredatı ve ilişkili tüm yapıyı topyekün gözden geçirip revize etmek anlamina gelir ${ }^{22}$.

Araştırmaya konu olan dersin öğretim programı Doll'un ${ }^{24}$ pragmatizm, postmodernizm ve karmaşıklık kuramı yoluyla oluşturduğu, salt müfredata dayalı okul sisteminden ziyade eğitsel eğitimi karşlayan, katı bir modelden ziyade eğitmenlerin kendi öğretim ortamlarında rahatlıkla kullanabilecekleri 4R modeliyle tasarlanmıştır. 4R modelinin tasarım öğeleri ve her bir öğenin dersin öğretim tasarımı içindeki fonksiyonu Tablo 1'de sunulmuştur.

Tablo 1: 4R Modeliyle hazırlanan öğretim programının öğeleri ve bu öğelerin fonksiyon analizi

\begin{tabular}{|c|c|c|}
\hline $\begin{array}{l}\text { 4R } \\
\text { Modelinin } \\
\text { Tasarımı } \\
\text { Öğeleri }\end{array}$ & & Tasarım Öğelerinin Fonksiyonları \\
\hline $\begin{array}{l}\text { Recursion } \\
\text { (Tekrar) }\end{array}$ & $:$ & $\begin{array}{l}\text { Tasarımın sarmal doğası gereği ana kavramların temalarla tekrarlanarak ele alınmasıdır. } \\
\text { Kavramları ve fikirleri öğrenene dikeyde ve yatayda tekrarlama, gözden geçirme ve yeniden } \\
\text { düşünme firsatı sunar. }\end{array}$ \\
\hline $\begin{array}{l}\text { Rigor } \\
\text { (Özen) }\end{array}$ & $:$ & $\begin{array}{l}\text { Tasarımın ve öğrencinin bir dereceye kadar kendini organize etme esnekliğidir. Öğrenene } \\
\text { katı disiplinin edilgen tüketiminden ziyade sorgulama, iletişim, eleştirel düşünme, problem } \\
\text { çözme gibi bütünleştirici öğrenme stratejilerini kullanabilecekleri problem temelli içerik } \\
\text { sunar. }\end{array}$ \\
\hline $\begin{array}{l}\text { Richness } \\
\text { (Zenginlik) }\end{array}$ & $:$ & $\begin{array}{l}\text { Derin öğrenmeyi teşvik eden dönüştürücü deneyimlerin tasarımla birleştirilmesidir. } \\
\text { Öğrenene performans görevleri, proje ödevleri, portfolyolar, özdeğerlendirme, eleştirel } \\
\text { düşünme, yansıtma, pratik uygulama gibi derin öğrenme stratejileri aracılığıyla öğrenme ve } \\
\text { bilgiyi farklı durumlara uygulama firsatı verilir. }\end{array}$ \\
\hline $\begin{array}{l}\text { Relations } \\
\text { (İlişkiler) }\end{array}$ & $:$ & $\begin{array}{l}\text { Tasarımın bütünsel doğasını işaret eder. Bilginin pedagojik/androgojik ve kültürel bağlam } \\
\text { aracılığıyla transferinin sağlanmasıdır. Sosyal diyalog ve anlatımla kapsamın ve anlamın } \\
\text { kollektif inşaasına imkân verir. Öğrenene bağlam temelli özdeğerlendirme ve akran } \\
\text { değerlendirme etkinlikleriyle kendini ifade etme ve yansıtma firsatı sunar. }\end{array}$ \\
\hline
\end{tabular}

(Curren, Harris ve Hill 2012'den yararlanılarak oluşturulmuştur.) 
Tablo 1'den de takip edilebildiği gibi araştırmaya konu olan dersin öğretim tasarımı dört temel öğe esas alınarak hazırlanmıştır. Bununla birlikte Cullen, Harris ve Hill ${ }^{22} 4 \mathrm{R}$ tasarımıyla öğrenen merkezli sürecin işleyişinde Doll'un önerdiği üç temel prensip olan “topluluk oluşturma”, "gücün paylaşımı” ve “değerlendirme”yi de şu şekilde açılar: Topluluk oluşturma, işbirliğini teşvik eder, takım olmayı ve aktif öğrenmeyi sağlar. Gücün paylaşımı, öğrenenin hem akademik plana dâhil olmasını sağlar hem de yetkinliklerini ve kendini ifadesine alternatif bir imkân sunar. Değerlendirme ise öğreneni bilgiyi farklı bağlamlarda uygulamasını esas alan etkinliklere dâhil eder. Müfredatta yer alan kazanımlara sadık kalınmak kaydıyla, yukarıda ifade edilen temel prensiplere göre belirlenen ders temaları ilgili kazanımlarla eşleştirilerek Tablo 2'de verilmiştir.

Tablo 2: Kişilerarası ilişkiler ve terapötik iletişim dersinin tema bazlı ders kazanımları

\begin{tabular}{|c|c|c|c|c|c|c|c|c|c|c|c|}
\hline \multirow[b]{2}{*}{ Kazanımlar } & \multirow[b]{2}{*}{$\begin{array}{l}\text { Kazanım } \\
\text { Türüi }\end{array}$} & \multicolumn{10}{|c|}{ Temalar } \\
\hline & & 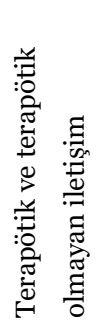 & 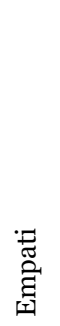 & 节 & $\underset{\tilde{\Xi}}{\tilde{\Xi}}$ & 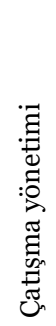 & 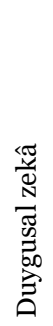 & 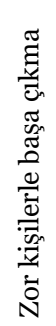 & 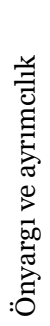 & 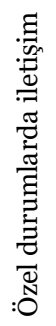 & 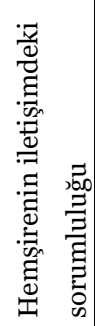 \\
\hline $\begin{array}{l}\text { Kişilerarası ilişki } \\
\text { mekanizmalarını } \\
\text { etkin olarak } \\
\text { kullanır. }\end{array}$ & $\begin{array}{l}\text { Duyuşsal } \\
\text { Karakterize } \\
\text { etme }\end{array}$ & & $\mathbf{x}$ & $\mathbf{X}$ & $\mathbf{X}$ & $\mathbf{X}$ & $\mathbf{X}$ & $\mathbf{X}$ & $\mathbf{X}$ & $\mathbf{X}$ & \\
\hline $\begin{array}{l}\text { Kişisel } \\
\text { farkındalık } \\
\text { kazanır. }\end{array}$ & $\begin{array}{l}\text { Duyuşsal } \\
\text { Algılama }\end{array}$ & $\mathbf{X}$ & $\mathbf{X}$ & $\mathbf{X}$ & $\mathbf{X}$ & $\mathbf{X}$ & $\mathbf{x}$ & $\mathbf{X}$ & $\mathbf{X}$ & $\mathbf{X}$ & $\mathbf{X}$ \\
\hline $\begin{array}{l}\text { Mesleki } \\
\text { uygulamalarda } \\
\text { tedavi edici } \\
\text { etmenlerden } \\
\text { yararlanır. }\end{array}$ & $\begin{array}{l}\text { Duyuşsal } \\
\text { Karakterize } \\
\text { etme }\end{array}$ & $\mathbf{x}$ & $\mathbf{x}$ & $\mathbf{X}$ & $\mathbf{X}$ & $\mathbf{x}$ & $\mathbf{x}$ & $\mathbf{X}$ & $\mathbf{x}$ & $\mathbf{x}$ & $\mathbf{x}$ \\
\hline $\begin{array}{l}\text { Kişilerarası } \\
\text { ilişkilerde } \\
\text { görülen } \\
\text { patolojilerin } \\
\text { farkına varır. }\end{array}$ & $\begin{array}{l}\text { Duyuşsal } \\
\text { Algılama }\end{array}$ & & & & & & $\mathbf{X}$ & $\mathbf{X}$ & $\mathbf{X}$ & $\mathbf{X}$ & $\mathbf{x}$ \\
\hline
\end{tabular}


Araştırmaya konu olan ve Tablo 2'de yer verilen kazanımları hedefleyen dersin öğrenen merkezli öğretim programının değerlendirilmesinde CIPP modeli esas alınmıştır. CIPP değerlendirme modeli, eğitim programlarının, projelerin, personelin, ürünlerin, kuruluşların, prensiplerin ve değerlendirme sistemlerinin biçimlendirici ve özetleyici şekilde değerlendirilmelerini sağlayan kapsamlı bir yapıdır. Temelde bu model bağlamın, girdilerin, sürecin ve çlktıların incelenmesi için yönlendirmelerde bulunur 25 . Stufflebeam'e ${ }^{25}$ göre, CIPP modelin temel ilkesi şudur: Değerlendirmenin amacı yalnızca kanıtlamak değil, bunun yanında ve daha önemlisi de gelişmektir. Dolayısıyla değerlendirme, ilk ve en önemlisi uzun vadede aydınlatıcı, yardım edici ve girişimleri güçlendirip geliştirmek için çalışmaya teşvik edici işlevsel bir faaliyet olarak düşünülmüştür. Genel hatlarıyla bu plan çerçevesinde hazırlanan dersin öğrenen merkezli öğretim programını değerlendirmek üzere şu iki soruya yanıt aranmıştır: (1) Hemşirelik Lisans öğrencilerinin Kişilerarası İlişkiler ve Terapötik İletişim dersinin öğretim programına ilişkin görüşleri arasında programın bağlam, girdi, süreç ve çıtı değerlendirme boyutlarına göre ilişki var mıdır? (2) Hemşirelik Lisans öğrencilerinin Kişilerarası İlişkiler ve Terapötik İletişim dersinin bağlam, girdi, süreç ve çıtı boyutlarına ilişkin görüşleri, cinsiyetlerine göre, alandaki eğitim geçmişlerine göre, akademik yeterlilik algılarına göre, sosyal ilişkilerdeki yeterlilik algılarına göre, duygusal yardım becerilerindeki yeterlilik algılarına göre farklılaşmakta mıdır? Araştırmanın diğer araştırmacılara, hedeflenen mesleki yetkinliklere ulaşabilmek için araştırma sorularının odağına "sağlıkta iletişim eğitimleri nasıl tasarlanmalı ve nasıl değerlendirilmelidir” problemini alması; uygulayıcılara ise öğrenen merkezli program tasarımı ve öğrenen merkezli program değerlendirme sürecine getirmiş olduğu pratik model açısından yardımcı olabileceği düşünülmektedir.

\section{Gereç ve Yöntem}

Araştırmanın çalışma grubunu, 2017-2018 Bahar döneminde, İstanbul Gelişim Üniversitesi Sağlık Yüksekokulu Hemşirelik Bölümü lisans programına kayıtlı, Kişilerarası İlişkiler ve Terapötik İletişim dersine devam eden 52 öğrenci oluşturmaktadır.

Araştırmanın veri toplama aracı, Kavgaoğlu ve $\mathrm{Alc1}^{26,27}$ tarafından geliştirilen "CIPP Program Değerlendirme Ölçeği”dir. Ölçek, programın hedefleri, konuları, ilgi, ihtiyaç 
ve beklentilerle uyumu, eğitim ortamı, eğitim süreleri ve zaman planını değerlendiren Bağlam boyutunda 15 madde; programda kullanılan eğitim materyalleri, içerik-temalar ve öğretim elemanının kolaylaştırıcılığını değerlendiren Girdi boyutunda 9 madde; öğretim elemanlarının süreç yönetimini, etkinliklerini, kullandıkları öğretim yöntem ve tekniklerini değerlendiren Süreç boyutunda 15 madde ve programın değerlendirme etkinliklerine yönelik görüşlere ve programla ilgili özdeğerlendirmelere yer veren Çıktı boyutunda 20 madde olmak üzere toplam 59 maddeden oluşmaktadır. Yanıt seçenekleri beşli Likert tipi olarak tasarlanmıştır. Likert tipi ölçekte yer alan maddeler; (5) Tamamen Katılıyorum; (4) Katılıyorum; (3) Kısmen Katılıyorum; (2) Katılmıyorum; (1) Kesinlikle Katılmıyorum şeklinde puanlanmaktadır. Ölçeğin yapı geçerliliği için faktör analizi yapılmıştır (KMO:0,97; Bartlett p=0.00). Bu Faktörler; Bağlam 1 (hedefler), Bağlam 2 (fırsatlar ve kaynaklar); Girdi, Süreç, Çıktı 1 (bireysel çıktılar), Çıktı 2 (iş ve sosyal hayata yönelik çıtılar)'dir. Ölçeğin toplam açıklanan varyansı \%67,874'tür. Ölçeği oluşturan altı faktörü doğrulama maksadıyla doğrulayıcı faktör analizi de yapılmış uyum indekslerinin anlamlı olduğu sonucuna varılmıştır. İçsel tutarlılı̆̆ı ölçmek için Cronbach Alfa değerine bakılmıştır. o,6o ve üzeri olması beklenen bu değerin o,98 olduğu tespit edilmiştir. Yani ölçeğe ve boyutlarına ilişkin ifadelerin iç tutarlılı̆̆ı yüksek olup ölçek yüksek derecede güvenilir bir ölçektir²6. Ölçeğin giriş kısmında, katılımcıların görüşlerini etkileyebileceği düşünülen cinsiyet, alandaki eğitim geçmişi, akademik yeterlilik algısı, sosyal ilişkilerdeki yeterlilik algısı, duygusal yardım becerilerine yönelik yeterlilik algısı gibi veriler kişisel bilgiler formuyla alınmıştır. Katılımcı görüşleri CIPP Program Değerlendirme Ölçeği ile 26 Nisan-10 Mayıs 2018 tarihleri arasında alınmıştır. Uygulama öncesinde katılımcılara ölçme aracı hakkında bilgi verilmiştir. Katılımcıların ölçeği doldurma süresi 15-25 dakika arasında değişmiştir. Araştırmanın veri analizi 52 öğrencinin ölçeğe verdiği geçerli cevaplar dikkate alınarak SPSS v25.o paket programıyla gerçekleştirilmiştir. Araştırmanın istatistiksel çözümlemeleri betimsel analiz, güvenilirlik, farklılık ve korelasyon analizleri ile yapılmıştır. CIPP ölçeğine ait görüşlerin dağılımının normalliği Kolmogorov-Smirnov Testi ile incelenmiş test sonucuna göre değişkenlerin normal dağılım göstermediği saptandığından ( $\mathrm{p}<0.05)$ çözümlemelerde non-parametrik teknikler olan "Mann Whitney U Testi”, "Kruskal Wallis Analizi”, "Spearman's Rho Testi” kullanılmıştır. Modelin ara değişkenlerinin aracılık etkisini belirleyebilmek için “Hiyerarşik Regresyon Analizi” yapılmıştır. CIPP ölçeğine ait tanımlayıcı değerlere, 
değişkenlerin birbirleriyle ilişkilerine yönelik analizlere ve farklılık testlerine geçmeden önce sorular birleştirilerek güvenilirlik analizine tabi tutulmuştur. Güvenilirlik analizlerinde, içsel tutarlılığı ölçmede Cronbach’s Alpha katsayısı dikkate alınmıştır. Ölçeğin genel güvenilirlik katsayısı 0.969 olarak tespit edilmiştir. Bu durumda Alpha katsayısına bağlı olarak ölçeğin güvenilirliği $0.80 \leq \alpha<1.00$ koşulunu sağladığı için ölçek yüksek derecede güvenilir bir ölçek olarak kabul edilmektedir ${ }^{28}$. Analiz sonucunda elde edilen değerler, literatürde öngörülen 0.60 alt limit kriterini sağladığı için araştırmada kullanılan ölçeğe ilişkin ifadelerin yüksek derecede içsel tutarlılığı olduğunu söylemek mümkündür29,30. Araştırma için 26.04.2018 tarih ve 2018-10-8 sayılı yazı ile İstanbul Gelişim Üniversitesi Etik Kurulundan onay alınmıştır.

\section{Bulgular}

Araştırmanın ilişkin bulgular, katılımcıların kişisel özelliklerine ve ölçeğe ilişkin betimsel analiz sonuçlarını takiben sırasıyla birinci ve ikinci araştırma sorularına yönelik olarak takip eden kısımda yer almaktadır. Araştırmaya katılan 52 öğrenciye ait betimsel analiz sonuçları Tablo 3 ’te görülmektedir.

Tablo 3: Katılımcıların demografik özellikleri $(n=52)$

\begin{tabular}{|l|l|l|}
\hline Gruplar & n & Yüzde \\
\hline Cinsiyet & 43 & 82.7 \\
\hline Kadın & 9 & 17.3 \\
\hline Erkek & 15 & 28.8 \\
\hline Alandaki Ĕ̆itim & 37 & 71.2 \\
\hline Meslek Lisesi Mezunu & \multicolumn{3}{|l|}{} \\
\hline Alandaki İlk Üniversite & 4 & 7.7 \\
\hline Akademik Başarı Düzeyine Yönelik Öz Değerlendirme \\
\hline Çok İyi & 30 & 57.7 \\
\hline İyi & 15 & 28.8 \\
\hline Orta & 3 & 5.8 \\
\hline Kötü & 0 & 0.0 \\
\hline Çok Kötü & 10 & 19.2 \\
\hline Sosyal İlişki Düzeyine Yönelik Öz Değerlendirme & \multicolumn{3}{|l|}{} \\
\hline Çok İyi & 36 & 69.2 \\
\hline İyi & \multicolumn{3}{|l|}{} \\
\hline
\end{tabular}




\begin{tabular}{|l|l|l|}
\hline Orta & 6 & 11.5 \\
\hline Kötü & 0 & 0.0 \\
\hline Çok Kötü & 0 & 0.0 \\
\hline Duygusal Yardım Becerisi Düzeyine Yönelik Öz Değerlendirme \\
\hline Çok İyi & 18 & 34.6 \\
\hline İyi & 29 & 55.8 \\
\hline Orta & 5 & 9.6 \\
\hline Kötü & 0 & 0.0 \\
\hline Çok Kötü & 0 & 0.0 \\
\hline
\end{tabular}

Tablo 3’ten de takip edilebileceği gibi öğrencilerin \%82.7'si kadın, \%17.3'ü erkek; \%71.2'sinin alanındaki ilk üniversitesi, \%28.8'i ise ilgili meslek lisesi mezunudur. Öğrencilerin \%57.7'si akademik başarı düzeyini; \%69.2'si sosyal ilişki düzeyini ve \%55.8’i duygusal yardım becerisi düzeyini iyi olarak belirtmektedir.

CIPP ölçeğinin boyutlarına ait betimsel bulgular ise Tablo 4'te sunulmaktadır.

Tablo 4: Ölçeğe ilişkin betimsel bulgular $(n=52)$

\begin{tabular}{|l|l|l|l|l|}
\hline Değişkenler & Minimum & Maksimum & $\bar{X}$ & Std. Sp. \\
\hline Bağlam-1 & 3.78 & 5.00 & 4.71 & .33 \\
\hline Bă̆lam-2 & 2.83 & 5.00 & 4.53 & .56 \\
\hline Girdi & 3.33 & 5.00 & 4.64 & .48 \\
\hline Süreç & 3.40 & 5.00 & 4.80 & .37 \\
\hline Çıktı-1 & 3.23 & 5.00 & 4.75 & .44 \\
\hline Çıktı-2 & 3.00 & 5.00 & 4.68 & .53 \\
\hline
\end{tabular}

Tablo 4’ten de görüldüğü gibi 52 öğrencinin bağlam-1 ortalaması 4.71, standart sapması 0.33; bağlam-2 ortalaması 4.53, standart sapması 0.56; girdi ortalaması 4.64, standart sapması 0.48; süreç ortalaması 4.80, standart sapması 0.37; çıktı-1 ortalaması 4.75, standart sapması 0.44 ; çıtı-2 ortalaması 4.68, standart sapması 0.53 olarak 
bulunmuştur. Elde edilen değerler öğrencilerin boyutlardaki puanlama düzeylerinin yüksek olduğunu göstermektedir.

Araştırmanın "Hemşirelik Lisans öğrencilerinin Kişilerarası İlişkiler ve Terapötik İletişim dersinin öğretim programına ilişkin görüşleri arasında programın bağlam, girdi, süreç ve çıktı değerlendirme boyutlarına göre ilişki var mıdır?” şeklindeki birinci sorusu için öncelikle değişkenler arasındaki ilişkileri değerlendirmek üzere korelasyon analizi yapılmıştır. Tablo 5, 52 katılımcının değişkenler arasındaki ilişkileri ifade eden korelasyon katsayılarını göstermektedir. Tablodaki Spearman's rho korelasyon katsayıları araştırma değişkenleri arasındaki ilişkilere işaret etmektedir.

Tablo 5: Korelasyon analizi $(n=52)$

\begin{tabular}{|l|l|l|l|l|l|l|}
\hline Değişkenler & $\mathbf{1}$ & $\mathbf{2}$ & $\mathbf{3} \cdot$ & $\mathbf{4} \cdot$ & $\mathbf{5}$ & $\mathbf{6}$ \\
\hline 1. Bağlam-1 & 1 & & & & & \\
\hline 2. Bağlam-2 & $.525^{* *}$ & 1 & & & & \\
\hline 3. Girdi & $.689^{* *}$ & $.450^{* *}$ & 1 & & & \\
\hline 4. Süreç & $.562^{* *}$ & $.309^{*}$ & $.716^{* *}$ & 1 & & \\
\hline 5. Çıkt1-1 & $.617^{* *}$ & $.380^{* *}$ & $.672^{* *}$ & $.800^{* *}$ & 1 & \\
\hline 6. Ç1kt1-2 & $.662^{* *}$ & $.431^{* *}$ & $.646^{* *}$ & $.529^{* *}$ & $.545^{* *}$ & 1 \\
\hline
\end{tabular}

${ }^{* *} \mathrm{p}<0.01{ }^{*} \mathrm{p}<0.05$

Tablo 5’te sonuçlarına yer verilen korelasyon analizini takiben girdi ve sürecin, bağlam ile çıktı arasındaki ilişki üzerindeki aracılık etkisini belirleyebilmek için Baron ve Kenny tarafından önerilen üç aşamalı regresyon analizi uygulanmıştır. Bu kapsamda, öncelikle bağımsız değişken (bağlam) ile aracılık etkisine sahip olduğu düşünülen değişken (girdi ve süreç) arasında bir regresyon analizinin yapılması ve anlamlı bir ilişkinin olupolmadığının belirlenmesi gereklidir. İkinci olarak, bağımsız değişken (bağlam) ile bağımlı değişken (çıktı) arasındaki neden sonuç ilişkisi araştırılmalıdır. Son olarak, aracı değişken (girdi ve süreç) ile bağımlı değişkenin (çıktı) kontrol edildiği bir regresyon analizi yapılmalıdır. Bu analizler sonucunda, bir aracılık etkisinin olupolmadığını ortaya koyabilmek için; ikinci aşamada bağımsız değişkenin (bağlam) 
bağımlı değişken (çıktı) üzerindeki etkisinin tamamen ortadan kalkıp kalkmadığına bakılmalıdır. Bu noktada, etkide bir düşme görülüyor ve ilişki anlamlılığını sürdürüyorsa, kısmi aracılık etkisinden; etki tamamen ortadan kalkıyorsa tam aracılık etkisinden söz edilebilir. Bu aşamada, aracı değişken ile bağımlı değişken arasındaki ilişkinin anlamlılık düzeyini koruması da gerekmektedir. Bu amaçla araştırma modeli test edilirken "Hiyerarşik Regresyon Analizi” uygulanmıştır. Tablo 6, araştırma modeline ait hiyerarşik regresyon analizi sonuçlarını göstermektedir.

Tablo 6: Araştırma modeli ile ilgili hiyerarşik regresyon analizi $(n=52)$

\begin{tabular}{|c|c|c|c|c|c|}
\hline & $\begin{array}{l}\text { Standartlaştırılmamış } \\
\beta\end{array}$ & $\begin{array}{l}\text { Standartlaştırılmamış } \\
\text { Standart Hata }\end{array}$ & $\begin{array}{l}\text { Standartlaştırılmış } \\
\beta\end{array}$ & $\mathbf{F}$ & $\begin{array}{l}\mathbf{p} \\
\text { Değeri }\end{array}$ \\
\hline $\begin{array}{l}\text { Model } 1 \\
\text { Sabit }\end{array}$ & 1.650 & .666 & .548 & 21.473 & .000 \\
\hline Bağlam & .663 & .143 & & & \\
\hline $\begin{array}{l}\text { Model } 2 \\
\text { Sabit }\end{array}$ & -.258 & .488 & .032 & & .743 \\
\hline Girdi & .191 & .118 & .202 & & .113 \\
\hline Süreç & .816 & .155 & .667 & & .000 \\
\hline
\end{tabular}

Model 1 için $\mathrm{R}^{2}=0.300(\mathrm{p}<0.05)$; Model 2 için $\Delta \mathrm{R}^{2}=0.432(\mathrm{p}<0.05)$; $\mathrm{p}<0.05$

Tablo 6'da temsil edilen ilk model, sadece bağlam ile çıktı arasındaki ilişkiyi; 2. model ise bağlam bağımsız değişkeninin, girdi ve süreç ara değişkenleri olarak çıktı üzerindeki etkisini göstermektedir. İlk model varyansın \%30’unu açlklarken; girdi ve süreç eklendiğinde varyansın \%73'ünü açıklamaktadır. Yani ara değişken olarak eklenen girdi ve süreç varyansın toplam \%43’ünü daha açıklamaktadır. Analiz sonuçlarına göre; girdi ile çıktı arasında istatistiki bir ilişki bulunmamaktadır ( $\mathrm{p}>0.05$ ). Ancak, süreç değişkeni ile çıktı arasında istatistiki olarak anlamlı bir ilişki bulunmaktadır ( $\mathrm{p}<0.05)$. Bağlam bağımsız değişkeninin, süreç ara değişkeni olarak çıktı üzerinde istatistiki olarak etkilediği ve kısmi ara değişken etkisinin bulunduğu tespit edilmektedir ( $\beta=0.667$ $\mathrm{p}=0.000<0.05)$.

Araştırmanın "Hemşirelik Lisans öğrencilerinin Kişilerarası İlişkiler ve Terapötik İletişim dersinin bağlam, girdi, süreç ve çıktı boyutlarına ilişkin görüşleri, cinsiyetlerine 
göre, alandaki eğitim geçmişlerine göre, akademik yeterlilik algılarına göre, sosyal ilişkilerdeki yeterlilik algılarına göre, duygusal yardım becerilerindeki yeterlilik algılarına göre farklılaşmakta mıdır?” şeklindeki ikinci sorusu için her bir bağımsız değişen özelinde fark testleri yapılmıştır.

CIPP boyutları ile cinsiyetler arasındaki farklılık "Mann Whitney U Testi”ne göre analiz edilmiştir. Analiz sonuçları Tablo 7’de verilmektedir.

Tablo 7: Cinsiyete göre farklılık analizi

\begin{tabular}{|c|c|c|c|c|c|c|c|}
\hline Gruplar & Cinsiyet & $\mathbf{n}$ & $\begin{array}{l}\text { Siralar } \\
\text { Ortalaması }\end{array}$ & $\begin{array}{l}\text { Suralar } \\
\text { Toplamı }\end{array}$ & $\begin{array}{l}\text { Mann - } \\
\text { Whitney } \\
\text { U Değeri }\end{array}$ & $\begin{array}{l}Z \\
\text { Değeri }\end{array}$ & $\begin{array}{l}\text { p } \\
\text { Değeri }\end{array}$ \\
\hline \multirow{3}{*}{ Bağlam-1 } & Kadın & 43 & 24.43 & 1050.50 & \multirow{2}{*}{104.500} & \multirow{2}{*}{-2.243} & \multirow{2}{*}{.025} \\
\hline & Erkek & 9 & 36.39 & 327.50 & & & \\
\hline & Toplam & 52 & & & & & \\
\hline \multirow{3}{*}{ Bağlam-2 } & Kadın & 43 & 24.76 & 1064.50 & \multirow{2}{*}{118.500} & \multirow{2}{*}{-1.873} & \multirow{2}{*}{.061} \\
\hline & Erkek & 9 & 34.83 & 313.50 & & & \\
\hline & Toplam & 52 & & & & & \\
\hline \multirow{3}{*}{ Girdi } & Kadın & 43 & 24.42 & 1050.00 & \multirow{2}{*}{104.000} & \multirow{2}{*}{-2.256} & \multirow{2}{*}{.024} \\
\hline & Erkek & 9 & 36.44 & 328.00 & & & \\
\hline & Toplam & 52 & & & & & \\
\hline \multirow{3}{*}{ Süreç } & Kadın & 43 & 25.23 & 1085.00 & \multirow{2}{*}{139.000} & \multirow{2}{*}{-1.437} & \multirow{2}{*}{.151} \\
\hline & Erkek & 9 & 32.56 & 293.00 & & & \\
\hline & Toplam & 52 & & & & & \\
\hline \multirow{3}{*}{ Çıktı-1 } & Kadın & 43 & 25.42 & 1093.00 & \multirow{2}{*}{147.000} & \multirow{2}{*}{-1.188} & \multirow{2}{*}{.235} \\
\hline & Erkek & 9 & 31.67 & 285.00 & & & \\
\hline & Toplam & 52 & & & & & \\
\hline \multirow{3}{*}{ Çıktı-2 } & Kadın & 43 & 25.50 & 1096.50 & \multirow{2}{*}{150.500} & \multirow{2}{*}{-1.115} & \multirow{2}{*}{.265} \\
\hline & Erkek & 9 & 31.28 & 281.50 & & & \\
\hline & Toplam & 52 & & & & & \\
\hline
\end{tabular}

Tablo 7’ye göre, öğrencilerin bağlam-2, süreç, çıktı-1 ve çıktı-2 düzeyleri ile cinsiyet arasında istatistiki olarak anlamlı bir farklılık bulunmamaktadır ( $p>0.05)$. Ancak 
bağlam-1 ve girdi düzeyleri ile cinsiyet arasında istatistiki olarak anlamlı bir farklılık vardır $(\mathrm{p}<0.05)$. Analiz bulgularına göre, erkek öğrencilerin bağlam-1 ve girdi düzeylerinin kadın öğrencilerden daha yüksek olduğu saptanmaktadır.

CIPP boyutları ile alandaki eğitimleri arasındaki farklılık "Mann Whitney U Testi"ne göre analiz edilmiştir. Analiz sonuçları Tablo 8'de verilmektedir.

Tablo 8: Alandaki eğitime göre farklılık analizi

\begin{tabular}{|c|c|c|c|c|c|c|c|}
\hline Gruplar & Eğitim & $\mathbf{n}$ & $\begin{array}{l}\text { Suralar } \\
\text { Ortalaması }\end{array}$ & $\begin{array}{l}\text { Suralar } \\
\text { Toplamı }\end{array}$ & $\begin{array}{l}\text { Mann - } \\
\text { Whitney U } \\
\text { Değeri }\end{array}$ & $\begin{array}{l}Z \\
\text { Değeri }\end{array}$ & $\begin{array}{l}\mathbf{p} \\
\text { Değeri }\end{array}$ \\
\hline \multirow{3}{*}{ Bağlam-1 } & İlgili ML & 15 & 32.60 & 489.00 & \multirow{2}{*}{186.000} & \multirow{2}{*}{-1.925} & \multirow{2}{*}{.054} \\
\hline & İlk üni. & 37 & 24.03 & 889.00 & & & \\
\hline & Toplam & 52 & & & & & \\
\hline \multirow{3}{*}{ Bağlam-2 } & İlgili ML & 15 & 28.33 & 425.00 & \multirow{2}{*}{250.000} & \multirow{2}{*}{-.573} & \multirow{2}{*}{.566} \\
\hline & İlk üni. & 37 & 25.76 & 953.00 & & & \\
\hline & Toplam & 52 & & & & & \\
\hline \multirow{3}{*}{ Girdi } & İlgili ML & 15 & 27.07 & 406.00 & \multirow{2}{*}{269.000} & \multirow{2}{*}{-.179} & \multirow{2}{*}{.858} \\
\hline & İlk üni. & 37 & 26.27 & 972.00 & & & \\
\hline & Toplam & 52 & & & & & \\
\hline \multirow{3}{*}{ Süreç } & İlgili ML & 15 & 29.60 & 444.00 & \multirow{2}{*}{231.000} & \multirow{2}{*}{-1.023} & \multirow{2}{*}{.306} \\
\hline & İlk üni. & 37 & 25.24 & 934.00 & & & \\
\hline & Toplam & 52 & & & & & \\
\hline \multirow{3}{*}{ Çıtı-1 } & İlgili ML & 15 & 29.40 & 441.00 & \multirow{2}{*}{234.000} & \multirow{2}{*}{-.928} & \multirow{2}{*}{.353} \\
\hline & İlk üni. & 37 & $25 \cdot 32$ & 937.00 & & & \\
\hline & Toplam & 52 & & & & & \\
\hline \multirow{3}{*}{ Çılktı-2 } & İlgili ML & 15 & 31.07 & 466.00 & \multirow{2}{*}{209.000} & \multirow{2}{*}{-1.483} & \multirow{2}{*}{.138} \\
\hline & İlk üni. & 37 & 24.65 & 912.00 & & & \\
\hline & Toplam & 52 & & & & & \\
\hline
\end{tabular}

Tablo 8'deki analiz sonuçlarına göre, öğrencilerin boyutlardaki düzeyleri ile alandaki eğitimleri arasında istatistiki olarak anlamlı bir farklılık bulunmamaktadır (p>0.05). CIPP boyutları ile öğrencilerin akademik başarı öz değerlendirme düzeyi arasındaki farklılık “Kruskal Wallis Analizi”ne göre analiz edilmiştir. Analiz sonuçları Tablo 9'da verilmektedir. 
Tablo 9: Akademik başarı öz değerlendirme düzeyine göre farklılık analizi

\begin{tabular}{|c|c|c|c|c|c|c|}
\hline Gruplar & $\begin{array}{l}\text { Akademik Başarı } \\
\text { Ö.D. }\end{array}$ & $\mathbf{n}$ & $\begin{array}{l}\text { Siralar } \\
\text { Ortalaması }\end{array}$ & $\begin{array}{l}\text { Kruskal } \\
\text { Wallis H }\end{array}$ & Sd & $\begin{array}{l}\text { p } \\
\text { Değeri }\end{array}$ \\
\hline \multirow{5}{*}{ Bağlam-1 } & Çok İyi & 4 & 25.25 & \multirow{4}{*}{.262} & \multirow{4}{*}{3} & \multirow{4}{*}{.967} \\
\hline & İyi & 30 & 26.37 & & & \\
\hline & Orta & 15 & 26.30 & & & \\
\hline & Kötü & 3 & 30.50 & & & \\
\hline & Toplam & 52 & & & & \\
\hline \multirow{5}{*}{ Bağlam-2 } & Çok İyi & 4 & 19.50 & \multirow{4}{*}{1.452} & \multirow{4}{*}{3} & \multirow{4}{*}{693} \\
\hline & İyi & 30 & 26.30 & & & \\
\hline & Orta & 15 & 27.63 & & & \\
\hline & Kötü & 3 & 32.17 & & & \\
\hline & Toplam & 52 & & & & \\
\hline \multirow{5}{*}{ Girdi } & Çok İyi & 4 & 37.88 & \multirow{4}{*}{3.051} & \multirow{4}{*}{3} & \multirow{4}{*}{.384} \\
\hline & İyi & 30 & 25.12 & & & \\
\hline & Orta & 15 & 25.40 & & & \\
\hline & Kötü & 3 & 30.67 & & & \\
\hline & Toplam & 52 & & & & \\
\hline \multirow{5}{*}{ Süreç } & Çok İyi & 4 & 33.13 & \multirow{4}{*}{1.480} & \multirow{4}{*}{3} & \multirow{4}{*}{.687} \\
\hline & İyi & 30 & 25.40 & & & \\
\hline & Orta & 15 & 25.97 & & & \\
\hline & Kötü & 3 & 31.33 & & & \\
\hline & Toplam & 52 & & & & \\
\hline \multirow{5}{*}{ Çıktı-1 } & Çok İyi & 4 & 28.00 & \multirow{4}{*}{1.283} & \multirow{4}{*}{3} & \multirow{4}{*}{.733} \\
\hline & İyi & 30 & 27.62 & & & \\
\hline & Orta & 15 & 23.10 & & & \\
\hline & Kötü & 3 & 30.33 & & & \\
\hline & Toplam & 52 & & & & \\
\hline \multirow{5}{*}{ Çıktı-2 } & Çok İyi & 4 & 35.25 & \multirow{4}{*}{2.400} & \multirow{4}{*}{3} & \multirow{4}{*}{.494} \\
\hline & İyi & 30 & 26.02 & & & \\
\hline & Orta & 15 & 24.10 & & & \\
\hline & Kötü & 3 & 31.67 & & & \\
\hline & Toplam & 52 & & & & \\
\hline
\end{tabular}


Tablo 9’a göre, öğrencilerin boyutlardaki düzeyleri ile akademik başarı öz değerlendirme düzeyleri arasında istatistiki olarak anlamlı bir farklılık bulunmamaktadır (p>0.05). CIPP boyutları ile öğrencilerin sosyal ilişki öz değerlendirme düzeyi arasındaki farklılık "Kruskal Wallis Analizi”ne göre analiz edilmiştir. Analiz sonuçları Tablo 10’da verilmektedir.

Tablo 10: Sosyal ilişki öz değerlendirme düzeyine göre farklılık analizi

\begin{tabular}{|c|c|c|c|c|c|c|}
\hline Gruplar & $\begin{array}{l}\text { Sosyal İlişki } \\
\text { ö.D. }\end{array}$ & $\mathbf{n}$ & $\begin{array}{l}\text { Suralar } \\
\text { Ortalaması }\end{array}$ & $\begin{array}{l}\text { Kruskal } \\
\text { Wallis H }\end{array}$ & Sd & $\begin{array}{l}\text { p } \\
\text { Değeri }\end{array}$ \\
\hline \multirow{4}{*}{ Bağlam-1 } & Çok İyi & 10 & 31.40 & \multirow{3}{*}{1.516} & \multirow{3}{*}{2} & \multirow{3}{*}{.469} \\
\hline & İyi & 36 & 25.03 & & & \\
\hline & Orta & 6 & 27.17 & & & \\
\hline & Toplam & 52 & & & & \\
\hline \multirow{4}{*}{ Bağlam-2 } & Çok İyi & 10 & 27.15 & \multirow{3}{*}{1.536} & \multirow{3}{*}{2} & \multirow{3}{*}{.464} \\
\hline & $\overline{\text { İyi }}$ & 36 & 25.21 & & & \\
\hline & Orta & 6 & 33.17 & & & \\
\hline & Toplam & $5^{2}$ & & & & \\
\hline \multirow{4}{*}{ Girdi } & Çok İyi & 10 & 34.90 & \multirow{3}{*}{4.286} & \multirow{3}{*}{2} & \multirow{3}{*}{.117} \\
\hline & İyi & 36 & 24.86 & & & \\
\hline & Orta & 6 & 22.33 & & & \\
\hline & Toplam & 52 & & & & \\
\hline \multirow{4}{*}{ Süreç } & Çok İyi & 10 & 29.25 & \multirow{3}{*}{.712} & \multirow{3}{*}{2} & \multirow{3}{*}{.700} \\
\hline & İyi & 36 & 26.26 & & & \\
\hline & Orta & 6 & 23.33 & & & \\
\hline & Toplam & 52 & & & & \\
\hline \multirow{4}{*}{ Çıktı-1 } & Çok İyi & 10 & 32.65 & \multirow{3}{*}{2.541} & \multirow{3}{*}{2} & \multirow{3}{*}{.281} \\
\hline & $\overline{\text { İyi }}$ & 36 & 25.50 & & & \\
\hline & Orta & 6 & 22.25 & & & \\
\hline & Toplam & 52 & & & & \\
\hline \multirow{4}{*}{ Çıktı-2 } & Çok İyi & 10 & 32.30 & \multirow{3}{*}{2.309} & \multirow{3}{*}{2} & \multirow{3}{*}{.315} \\
\hline & İyi & 36 & 25.54 & & & \\
\hline & Orta & 6 & 22.58 & & & \\
\hline & Toplam & 52 & & & & \\
\hline
\end{tabular}


Tablo 10’a göre, öğrencilerin boyutlardaki düzeyleri ile sosyal ilişki öz değerlendirme düzeyleri arasında istatistiki olarak anlamlı bir farklılık bulunmamaktadır ( $\mathrm{p}>0.05$ ). CIPP boyutları ile öğrencilerin duygusal yardım becerilerine yönelik öz değerlendirme düzeyi arasındaki farklılık "Kruskal Wallis Analizi”ne göre analiz edilmiştir. Analiz sonuçları Tablo 11'de verilmektedir.

Tablo 11: Duygusal yardım becerileri öz değerlendirme düzeyine göre farklılık analizi

\begin{tabular}{|c|c|c|c|c|c|c|}
\hline Gruplar & $\begin{array}{l}\text { Duygusal Yardım } \\
\text { Becerileri Ö.D. }\end{array}$ & $\mathbf{n}$ & Suralar Ortalaması & Kruskal Wallis $\mathbf{H}$ & Sd & $\begin{array}{l}\text { p } \\
\text { Değeri }\end{array}$ \\
\hline \multirow{4}{*}{ Bağlam-1 } & Çok İyi & 18 & 30.97 & \multirow{3}{*}{6.245} & \multirow{3}{*}{2} & \multirow{3}{*}{.044} \\
\hline & İyi & 29 & 22.16 & & & \\
\hline & Orta & 5 & 35.60 & & & \\
\hline & Toplam & 52 & & & & \\
\hline \multirow{4}{*}{ Bağlam-2 } & Çok İyi & 18 & 28.61 & \multirow{3}{*}{2.685} & \multirow{3}{*}{2} & \multirow{3}{*}{.261} \\
\hline & $\begin{array}{l}\text { İyi } \\
\end{array}$ & 29 & 23.86 & & & \\
\hline & Orta & 5 & 34.20 & & & \\
\hline & Toplam & 52 & & & & \\
\hline \multirow{4}{*}{ Girdi } & Çok İyi & 18 & 27.72 & \multirow{3}{*}{1.773} & \multirow{3}{*}{2} & \multirow{3}{*}{.412} \\
\hline & İyi & 29 & 24.55 & & & \\
\hline & Orta & 5 & 33.40 & & & \\
\hline & Toplam & 52 & & & & \\
\hline \multirow{4}{*}{ Süreç } & Çok İyi & 18 & 29.22 & \multirow{3}{*}{2.392} & \multirow{3}{*}{2} & \multirow{3}{*}{.302} \\
\hline & $\overline{\text { İyi }}$ & 29 & 23.91 & & & \\
\hline & Orta & 5 & 31.70 & & & \\
\hline & Toplam & 52 & & & & \\
\hline \multirow{4}{*}{ Çıktı-1 } & Çok İyi & 18 & 29.86 & \multirow{3}{*}{3.281} & \multirow{3}{*}{2} & \multirow{3}{*}{.194} \\
\hline & $\overline{\text { İyi }}$ & 29 & 23.36 & & & \\
\hline & Orta & 5 & 32.60 & & & \\
\hline & Toplam & 52 & & & & \\
\hline \multirow{4}{*}{ Çıktı-2 } & Çok İyi & 18 & 30.67 & \multirow{3}{*}{4.044} & \multirow{3}{*}{2} & \multirow{3}{*}{.132} \\
\hline & $\overline{\text { İyi }}$ & 29 & 23.00 & & & \\
\hline & Orta & 5 & 31.80 & & & \\
\hline & Toplam & 52 & & & & \\
\hline
\end{tabular}


Tablo 11'deki bulgulara göre, öğrencilerin bağlam-2, girdi, süreç, çıktı-1 ve çıktı-2 düzeyleri ile duygusal yardım beceri düzeyleri arasında istatistiki olarak anlamlı bir farklılık bulunmamaktadır ( $\mathrm{p}>0.05$ ). Ancak bağlam-1 düzeyi ile duygusal yardım beceri düzeyleri arasında istatistiki olarak anlamlı bir farklılık vardır (p<0.05). Buna göre duygusal yardım becerisinin orta düzey olduğu öğrencilerin bağlam-1 düzeyleri diğer gruptakilerden daha yüksektir.

\section{Tartışma}

Hemşirelik araştırmalarına ilişkin literatür dikkate alındığında, bazı çalışmaların¹,32 hemşirelerin iletişim yetkinliklerini yaş, cinsiyet, kıdem, branş, medeni durum, çocuk sahibi olma, sosyo-demografik özellikler, görev yapılan klinikler gibi spesifik değişkenlere göre incelediği; bazı çalışmaların ${ }^{33-36}$ hemşire adaylarının iletişim yetkinliklerini öğrenim gördüğü sınıf kademesiyle ilişkilendirdiği; bazı çalışmaların $35,37,38$ iletişim becerilerini şekillendiren anne-baba etkisini merkeze aldığı; bazı çalışmaların da39-43 özgeci tutum, empati, benlik saygısı, çatışma çözümü, motivasyon, atılganlık düzeyi, stresle başa çıkma, eleştirel düşünme, problem çözme gibi temel iletişim yetkinliklerini değerlendirip müfredat geliştirmeye yönelik önerilerde bulunduğu göze çarpmaktadır.

Buraya kadar ifade edilen bilgiler çerçevesinde ilgili literatürün çoğunlukla hemşirelikte spesifik iletişim yetkinliklerine odaklandığı ve bu yetkinlikleri etkileyen değişkenleri tartıştı̆̆ı görülmektedir. İletişim yetkinliklerinin nasıl bir öğretim programıyla kazandırılabileceğine ve kazanımların nasıl değerlendirileceğine yönelik bir araştırma göze çarpmamıştır. Oysa önemli olan iletişim yetkinliklerinin hangi faktöre bağlı ne kadar değiştiği değil hangi öğretim programıla nasıl geliştirilebildiği olmalıdır. Bu konu müfredat tasarımını ilgilendirmektedir. Bu alanda ise yurt içinde ve yurt dışında yapılmış sınırlı sayıda araştırma mevcuttur ${ }^{44-51}$. Bu araştırmalar öğretim tasarımından ziyade iletişim becerilerinin yaşantısal öğrenme, problem tabanlı öğrenme, takım halinde öğrenme, drama tekniği ile öğrenme, simülasyonla öğrenme, karma (blended) öğrenme gibi yöntem ve tekniklerle geliştirilmesini konu almaktadır. Bu araştırmada ise literatürde öne çıkan çalışmalardan farklı olarak hemşirelik lisans programında yer alan "Kişilerarası İlişkiler ve Terapötik iletişim” dersinin öğrenen odaklı program tasarımıyla verilmesinin ders kazanımlarına ulaşma noktasında etkili bir yaklaşım olacağı tezi savunulmakta, öğrenen odaklı öğretimin etkisi öğrenci görüşleriyle 
değerlendirilmektedir. Bu amaçla süreç şu şekilde planlanmıştır; Yetişkin hemşire grubu için Hemşirelik kanunuyla belirlenen hemşirelik mesleğinin temel ilke ve prensipleri ve mesleğin girişim alanları dikkate alınarak değer temelli ve duyuşsal ağırlıklı olacak şekilde belirlenmiş müfredat kazanımları esas alınmıştır. Kapsam bu kazanımlar doğrultusunda tematik olarak planlanmış ve işleyiş Doll'un $4 \mathrm{R}$ modeli çerçevesinde öğrenen merkezli süreçlerle yürütülmüştür. Değerlendirme etkinlikleri öğrenci görüşleri de alınarak yapılmıştır. Seçilen kapsam dönem başında öğrencilerle paylaşılan bir izlenceyle sunulmuş her bir tema gönüllü küçük gruplara paylaştırılmıştır. Her bir öğrencinin araştırmak için heyecan duyduğu ve araştırmada mesleki gelişimi için fayda gördüğü konularla çalışması prensibi esas alınmıştır. Bireysel farklılıklar dikkate alınarak gruplara uygulayabilecekleri farklı araştırma metotları ve sunum teknikleri önerilmiş ancak gruplar konularını hazırlama ve sunma konusunda serbest bırakılmıştır. İşleyiş demokratik bir iklimle yürütülmüş tüm sınıfın rahatlıkla ve istediği zaman görüşlerini paylaşabileceği ve tartışabileceği esneklik sağlanmıştır. Tüm teorik eğitim kapsamı için sistematik olarak öğrencilerin "o halde bu bilgiyi nasıl kullanabilirim?” sorgusuyla akıl yürütmeleri ve somut uygulama örnekleri üretmeleri sağlanmıştır. Uygulamanın değerlendirilmesi neticesinde, öğrencilerin programın bağlam, girdi, süreç ve çıktı değerlendirme boyutlarına yönelik görüşleri arasındaki ilişkiyi inceleyen birinci sorusuna yönelik olarak yapılan analizde, öğrenen merkezli sürecin hakim olduğu işleyişi değerlendiren süreç değişkeni ile programın kişisel, sosyal ve iş sonuçlarına dönük etkilerini değerlendiren çıtı boyutu arasında istatistiki olarak anlamlı bir ilişki olduğu görülmüştür. Farklı bir ifadeyle uygulanan öğrenen merkezli öğretimin hedefine ulaştığı katılımcı görüşleriyle belirlenmiştir. Bununla birlikte öğretim programına ilişkin öğrenci görüşlerinin çeşitli değişkenler açısından farklılaşma durumuna odaklanan ikinci sorusuna yönelik olarak yapılan analizle ulaşılan bulgular da öğretim programının başarısını teyit eder niteliktedir. Nitekim öğrenci görüşleri alandaki eğitim geçmişi, algılanan akademik yeterlilik ve algılanan sosyal yeterlilik değişkenlerine göre farklılaşmamış tüm boyutlarda puanlamaların yüksek olduğu gözlenmiştir. Farklı bir ifadeyle alanda meslek lisesi bitirmiş olmanın sağladığı önbilgi avantajı, algılanan akademik başarının ve algılanan sosyal yeterliliğin yüksek olması öğrencilerin programı değerlendirme puanlarına tahmin edildiği şekilde olumsuz yansımamıştır. Önbilgisi, akademik ve sosyal beceri yeterlilik algısı yüksek öğrenciler de programı tüm boyutlarda yüksek puanlamıştır. 
Diğer taraftan analiz neticesinde cinsiyet ve duygusal yardım becerisine yönelik algı gibi bireysel farklılıkların öğrenme ortamının farklı yorumlanmasında etkili olduğu göze çarpmıştır. Erkek öğrencilerin hedeflerin ve kapsamın ilgi, ihtiyaç ve beklentiye uygunluğunu yoklayan bağlam boyutu ile eğitim yardımcı malzemelerine odaklanan girdi boyutunu daha yüksek puanladıkları görülmüştür. Cinsiyet ile ilgili stereotipler düşünme stilleri üzerine etkili olan değişkenlerden biridir ${ }^{2}$. Yurt dışında ve yurt içinde yapılmış bazı araştırmalar cinsiyet faktörünün düşünme stilleri üzerindeki etkisini kanıtlar niteliktedir53-57. Önemli olan öğretim ortamlarının cinsiyet faktörünü nötralize edebilecek kapsayıcı etkinliklerle desteklenebilmesini sağlayabilmektir. Bununla birlikte duygusal yardım becerisini yüksek tanımlamayan öğrencilerin bir kısmı hedeflerin ve kapsamın ilgi, ihtiyaç ve beklentiye uygunluğunu yoklayan bağlam boyutunu daha yüksek puanlamıştır. Bu durum da öğrencilerin, hemşirelik mesleğinin odağında bulunan terapötik iletişim yetkinliklerinin geliştirilmesi konusundaki motivasyonlarının bir göstergesi olarak yorumlanabilir.

\section{Sonuȩ}

Araştırmanın bulguları göz önüne alınarak devam eden araştırmalara yön verebilecek öneriler şu şekilde ifade edilebilir:

1. Bu araştırmada sağlıkta iletişimi konu alan bir dersin öğrenen merkezli öğretim programı değerlendirilmiştir. Takip eden araştırmalar, öğrenen merkezli tasarımla iletişim eğitimi alan hemşire adaylarının, kazanımlarını mesleki pratiklerine nasıl yansıttıklarını yerinde incelemeye yönelik saha çalışmalarını konu alabilir.

2. $\mathrm{Bu}$ araştırma hemşirelik birinci sınıf öğrencileriyle ve betimsel araştırma kapsamında gerçekleştirilmiştir. Takip eden araştırmalar hemşire adaylarının lisans programı boyunca iletişim yetkinliklerini takip edip geliştirmeye odaklanan boylamsal ve nitel tekniklerle kurgulanabilir.

3. Araştırmada cinsiyet ve algılanan duygusal yardım becerisi düzeyi gibi bireysel farklılıkların öğrenen merkezli öğrenme ortamının farklı yorumlanmasında etkili olabildiği gözlenmiştir. Takip eden araştırmalar bu iki bağımsız değişkenin etkilerinin öğrenen merkezli tasarımın içinde nasıl yönetilebileceğine odaklanabilir.

Araştırmanın bulguları göz önüne alınarak uygulayıcılara yön verebilecek öneriler şu şekilde ifade edilebilir: 
1. Yüksekokul genelinde akademik başarı ve öğrenci memnuniyetinin artırılması için dersler, yetişkin öğrenme prensiplerini ve bireysel farklılıkları da dikkate alan öğrenen merkezli öğretim tasarımlarıyla planlanabilir.

2. Terapötik iletişim derslerinin hemşirelik müfredatı içinde öğrenen merkezli etkinliklerle ve yaşantısal öğrenmeleri de içerecek şekilde, farklı öğretim kademelerinde genişleyerek tekrar eden spiral bir tasarımla verilmesi faydalı olabilir.

\section{KAYNAKLAR}

1. Yükseköğretim Kurulu. Türkiye'de sağlık eğitimi ve sağlık insangücü durum raporu https://sbu.saglik.gov.tr/Ekutuphane/kitaplar/insangucu.pdf. Yayımlanma tarihi Şubat 2014. Erişim tarihi 20 Ağustos 2018.

2. Türkiye İstatistik Kurumu. Sağlık personeli başına düşen kişi sayısı. İstatistiksel tablolar ve dinamik sorgulama. http://www.tuik.gov.tr/PreTablo.do?alt id= 1095. Yayımlanma tarihi Eylül 2017. Erişim tarihi 19 Temmuz 2018.

3. Yılmaz Ç. Beyaz Kod'a 67 bin şiddet başvurusu. Milliyet Gazetesi. http://www.milliyet.com.tr/beyaz-kod-a-67-bin-siddet-basvurusu-gundem2656624/. Yayımlanma tarihi 27 Nisan 2018. Erişim tarihi 19 Temmuz 2018.

4. Türkiye Büyük Millet Meclisi. Sağlık çalışanlarına yönelik artan şiddet olaylarının araştırılarak alınması gereken önlemlerin belirlenmesi amacıyla kurulan meclis araştırması komisyonu görüşme tutanakları.

https://www.tbmm.gov.tr/develop/owa/komisyon tutanaklari.goruntule?pTuta nakId=300. Yayımlanma tarihi Aralık 2012. Erişim tarihi 19 Temmuz 2018.

5. Türkiye Büyük Millet Meclisi. Meclis araştırması komisyonu raporu. https://www.tbmm.gov.tr/arastirma komisyonlari/saglik calisanlari/docs/ss45 4.pdf. Yayımlanma tarihi Ocak 2013. Erişim tarihi 16 Ağustos 2018.

6. Bostan S, Kılıç T, Çiftçi F. Sağlık Bakanlığı 184 SABİM hattına yapılan şikâyetlerin karşılaştırmalı analizi. Global Journal of Economics and Business Studies. 2014;3(5):32-40. 
7. Kayrakçı F, Özşaker E. Cerrahi hastalarının hemşirelik bakımından memnuniyet düzeylerinin belirlenmesi. Florence Nightingale Hemşirelik Dergisi. 2014;22(2):105-113.

8. Özkan Z. 66 Soruda Sağlıkta İletişimin Gücü, İstanbul: Optimist; 2011.

9. Geçkil E, Dündar Ö, Şahin T. Adıyaman il merkezindeki hastaların hemşirelik bakımından memnuniyet düzeylerinin değerlendirilmesi. Hacettepe Üniversitesi Sağlık Bilimleri Fakültesi Hemşirelik Dergisi. 2008;15(2):41-51.

10. Arslan Ç, Kelleci M. Bir üniversite hastanesinde yatan hastaların hemşirelik bakımından memnuniyet düzeyleri ve ilişkili bazı faktörler. Anadolu Hemşirelik ve Sağlık Bilimleri Dergisi. 2011;14(1):1-8.

11. Cerit B. Hastaların hemşirelik bakımından memnuniyet düzeyi. Hacettepe Üniversitesi Hemşirelik Fakültesi Dergisi. 2016;3(1):27-36.

12. Demir Y, Gürol Arslan G, Eşer İ, Khorshid L. Bir eğitim hastanesinde hastaların hemşirelik hizmetlerinden memnuniyet düzeylerinin incelenmesi. Istanbul Üniversitesi Florence Nightingale Hemşirelik Dergisi. 2011;19(2):68-76.

13. Kuzu C, Ulus B. Cerrahi kliniklerde tedavi gören hastaların aldıkları hemşirelik bakımından memnuniyet durumlarının belirlenmesi. Acıbadem Üniversitesi Sağlık Bilimleri Dergisi. 2014;5(2):129-134.

14. Okgün Alcan A, Yavuz Van Giersbergen M, Şahin Köze B, Tanıl V, İyik Aksakal B. Hastaların hemşirelik hizmetlerinden memnuniyet düzeyleri. Ege Üniversitesi Hemşirelik Fakültesi Dergisi. 2015;31(3):81-89.

15. Şişe Ş. Hastaların hemşirelik hizmetlerinden memnuniyeti. Kocatepe Tıp Dergisi. 2013;14(2):69-75.

16. Tuğut N, Gölbaşı Z. Bir üniversite hastanesi kadın hastalıkları ve doğum servisinde yatan hastaların hemşirelik hizmetlerinden memnuniyet düzeyleri ve etkileyen bazı faktörler. Hemşirelikte Eğitim ve Araştırma Dergisi. 2013;10(2):38-44.

17. Kıvanç Altunay. İ. Psychoneuroimmunology and multifactorial psychodermatological diseases. Türkderm. 2010;44(1):10-15. doi:10.4274/turkderm.s44.10.

18. Hemşirelik Eğitimi Derneği. Hemşirelik ulusal çekirdek programı HUÇEP 2014. http://www.hemed.org.tr/images/stories/hucep-2014-pdf.pdf. Yayımlanma tarihi Şubat 2016. Erişim tarihi 16 Ağustos 2018.

19. Hewitt TW. Eğitimde Program Geliştirme. Ankara: Nobel Yayınevi; 2018. 
20. Ornstein AC, Hunkins FP, eds. Eğitim Programı Temeller İlkeler ve Sorunlar. Konya: Ĕ̆itim Yayınevi; 2014.

21. Demirel Ö. Eğitimde Program Geliştirme. Ankara: Pegem A Yayıncılı; 2007.

22. Cullen RM, Harris M, Hill RR. The learner-centered curriculum: design and implementation. San Francisco, CA: Jossey-Bass; 2012.

23. Weimer M. Learner-centered teaching: five key changes to practice. San Francisco, CA: Jossey-Bass; 2013.

24. Demirkaya H. Donna Trueit, pragmatism, post-modernism, and complexity theory the "fascinating imaginative realm" of William E. Doll, Jr. Uluslararası Sosyal ve Eğitim Bilimleri Dergisi. 2016;3(5):156-159. doi:10.20860/ijoses.14615.

25. Stufflebam DL, Coryn CLS. Evaluation, Theory, Models \& Applications. JosseyBASS: USA; 2014.

26. Kavgaoğlu D. Çağrı Merkezi Mesleki Yetkinlik Geliştirme Eğitim Programının Değerlendirilmesi. [doktora tezi]. İstanbul, Türkiye: Yıldız Teknik Üniversitesi Sosyal Bilimler Enstitüsü; 2017.

27. Kavgaoğlu D, Alcı B. Application of context input process and product model in curriculum evaluation: case study of a call centre. Educational Research and Reviews. 2016;11(17):1659-1669.

28. Kalaycı Ş. SPSS Uygulamalı Çok Değişkenli İstatistik Teknikleri. 4. baskı. Ankara: Asil Yayın Dağıtım; 2009.

29. Cronbach LJ. Essentials of Psychological Testing. 5th ed. New York: Harper Collins; 1990.

30. Punch K. Introduction to Social Research - Quantitive and Qualitive Approach. 2nd ed. California: Sage Publications Inc; 2005.

31. Dizer B, İyigün E. Yoğun bakım hemşirelerinde empatik eğilim düzeyleri ve etkileyen faktörler. Anadolu Hemşirelik ve Sağlık Bilimleri Dergisi. 2010;12(1):919.

32. Tiryaki Şen H, Taşkın Yılmaz F, Pekşen Ünüvar Ö, Demirkaya F. Birinci basamak sağlık hizmetlerinde görev yapan sağlık çalışanlarının empatik beceri düzeyleri. Psikiyatri Hemşireliği Dergisi. 2012;3(1):6-12. 
33. Atay S, Ekim E, Gökkaya S, Sağım E. Sağlık Yüksekokulu öğrencilerinin eleştirel düşünme düzeyleri. Hacettepe University Faculty of Health Sciences Nursing Journal. 2009;16(1):39-46.

34. Duman D, Acaroğlu R. Hemşirelik yüksekokulu birinci sınıf öğrencilerinin duygusal zekâ düzeyleri ile empati becerileri arasındaki ilişki. Florence Nightingale Hemşirelik Dergisi. 2014;22(1):25-32.

35. Erigüç G, Şener T, Eriş H. İletişim becerilerinin değerlendirilmesi: bir meslek yüksekokulu öğrencileri örneği. Hacettepe Sağlık İdaresi Dergisi. 2014;16(1):4565.

36. Kumcağız H, Yılmaz M, Balcı Çelik S, Aydın Avcı İ. Hemşirelerin iletişim becerileri: Samsun ili örneği. Dicle Tip Dergisi. 2011;38(1):49-56.

37. Can Gürkan Ö. Nursing students' tendency to aggression and relevant factors. Journal of Psychiatric Nursing/Psikiyatri Hemşireleri Derneği. 2016;7(2):87-93. doi:10.5505/phd.2016.19870.

38. Özeren GS. Bir Grup Hemşirelik Öğrencisinde Anne-Baba Bağlanma Biçimlerinin Kişilerarası İlişkilere Etkisi. [doktora tezi]. İstanbul, Türkiye: Bilim Üniversitesi Sağlık Bilimleri Enstitüsü; 2016.

39. Şahin Altun Ö, Ekinci M. The effect of conflict resolution training on the conflict resolution skills of nursing students. Journal of Psychiatric Nursing/Psikiyatri Hemşireleri Derneği. 2015;6(3):105-113. doi:10.5505/phd.2015.63856.

40. Çam O, Pektaş İ, Bilge A. Ebe/hemşirelere verilen ruh sağlı̆̆ı ve hastalıkları eğitiminin ruhsal hastalıklara yaklaşımlarına iletişim becerilerine ve iş doyumlarına etkilerinin araştırılması. Atatürk Üniversitesi Hemşirelik Yüksekokulu Dergisi. 2007;10(3):7-15.

41. Şimşek M, Çonoğlu G, Orgun F. Hemşirelik eğitiminde kazandırılması planlanan hemşirelik becerilerinin değerlendirilmesi. Ege Üniversitesi Hemşirelik Fakültesi Dergisi. 2018;34(1):1-25.

42. Kanbay Y. Hemşirelik Öğrencilerine Verilen Eleştirel Düşünme Eğitiminin Problem Çözme Becerisi Üzerine Etkisi. [doktora tezi]. Erzurum, Türkiye: Atatürk Üniversitesi Sağlık Bilimleri Enstitüsü; 2013.

43. Özkan İA, Özen A. Öğrenci hemşirelerde boyun eğici davranışlar ve benlik saygısı arasındaki ilişki. TSK Koruyucu Hekimlik Bülteni. 2008;7(1):53-58. 
44. Ortabă̆ T, Tosun N, Bebiş H, Yava A, Çiçek HS, Akbayrak N. Yatağın diğer tarafı: hemşirelik yüksekokulu birinci sınıf öğrencilerinin eğitim amaçlı hastaneye yatma deneyimleri. Gulhane Medical Journal. 2010;52(3):189-197.

45. Deeny P, Johnson A, Boore J, Leyden C, McCaughan E. Drama as an experiential technique in learning how to cope with dying patients and their families. Teaching In Higher Education. 2001;6(1):99-112. doi:10.1080/13562510020029635.

46. Doucet S, Buchanan J, Cole T, McCoy CA. Team approach to an undergraduate interprofessional communication course. Journal of Interprofessional Care. 2013;27(3):272-273. doi:10.3109/13561820.2012.743978.

47. Furnes M, Kvaal KS, Høye S. Communication in mental health nursing - bachelor students' appraisal of a blended learning training programme - an exploratory study. BMC Nursing. 2018;17(20):1-10. doi:10.1186/s12912-018-0288-9.

48. Hagemeier NE, Hess R, Hagen KS, Sorah EL. Impact of an interprofessional communication course on nursing, medical, and pharmacy students' communication skill self-efficacy beliefs. American Journal of Pharmaceutical Education. 2014;78(10):1-10.

49. Mert H, Sezgin D. Geleneksel ve probleme dayalı öğrenim modeliyle öğrenim gören hemşirelik öğrencilerinin empatik beceri düzeylerinin incelenmesi. Anadolu Hemşirelik ve Sağhk Bilimleri Dergisi. 2011;14(1):9-13.

50. Ramsay J, Keith G, Ker JS. Use of simulated patients for a communication skills exercise. Nursing Standard/Royal College of Nursing (Great Britain). 2008;22(19):39-44. doi: 10.7748/ns2008.01.22.19.39.c6313.

51. Reams S, Bashford C. Interdisciplinary role play: nursing and theater students advance skills in communication. Delta Kappa Gamma Bulletin. 2011;77(4):4248.

52. Kavgaoğlu D, Altun S. Examination of teachers' thinking style according to their branchand gender. The Journal of International Education Science. 2016;3 (6):136-149.

53. Tucker RW. An Examination of Accounting Students Thinking Styles [doctoral thesis]. Moscow: University of Idaho; 1999. 
54. May Leng H, Maarof N. Thinking styles of teacher trainees in four teacher training institutes in Malaysia. International Journal of Learning. 2009;16(8):473-484. doi: 10.18848/1447-9494/CGP/v16io8/46533.

55. Çubukçu, Z. Öğretmen adaylarının düşünme stillerinin belirlenmesi. Trakya Üniversitesi Sosyal Bilimler Dergisi. 2004;5(2):87-106.

56. Dinç AP, Bal A. Lise Öğrencilerin geometri başarısı ve düşünme stillerinin karşılaştırılması. Çukurova Üniversitesi Sosyal Bilimler Enstitüsü Dergisi. 2008;17(1):1-10.

57. Yıldızlar M. Farklı kültürlerden gelen öğretmen adaylarının düşünme stilleri. Hacettepe Üniversitesi Eğitim Fakültesi Dergisi. 2010;39(39):383-393. 